\title{
Cancer immunotherapy via combining oncolytic virotherapy with chemotherapy: recent advances
}

This article was published in the following Dove Press journal:

Oncolytic Virotherapy

6 January 2016

Number of times this article has been viewed

\author{
Guy R Simpson' \\ Kate Relph' \\ Kevin Harrington ${ }^{2}$ \\ Alan Melcher ${ }^{3}$ \\ Hardev Pandha' \\ 'Department of Clinical and \\ Experimental Medicine, Targeted \\ Cancer Therapy, Faculty of Health \\ and Medical Sciences, University of \\ Surrey, Guildford, ${ }^{2}$ Targeted Therapy, \\ The Institute of Cancer Research/ \\ The Royal Marsden NIHR Biomedical \\ Research Centre, London, ${ }^{3}$ Targeted \\ and Biological Therapies, Oncology \\ and Clinical Research, Leeds Institute \\ of Cancer and Pathology, Faculty of \\ Medicine and Health, University of \\ Leeds, Leeds, UK
}

\begin{abstract}
Oncolytic viruses are multifunctional anticancer agents with huge clinical potential, and have recently passed the randomized Phase III clinical trial hurdle. Both wild-type and engineered viruses have been selected for targeting of specific cancers, to elicit cytotoxicity, and also to generate antitumor immunity. Single-agent oncolytic virotherapy treatments have resulted in modest effects in the clinic. There is increasing interest in their combination with cytotoxic agents, radiotherapy and immune-checkpoint inhibitors. Similarly to oncolytic viruses, the benefits of chemotherapeutic agents may be that they induce systemic antitumor immunity through the induction of immunogenic cell death of cancer cells. Combining these two treatment modalities has to date resulted in significant potential in vitro and in vivo synergies through various mechanisms without any apparent additional toxicities. Chemotherapy has been and will continue to be integral to the management of advanced cancers. This review therefore focuses on the potential for a number of common cytotoxic agents to be combined with clinically relevant oncolytic viruses. In many cases, this combined approach has already advanced to the clinical trial arena.
\end{abstract}

Keywords: oncolytic virotherapy, chemotherapy, immunogenic cell death

\section{Introduction}

The conventional cancer treatments of surgery, chemotherapy, and radiotherapy remain the mainstay of current therapeutic approaches to cancer. They have been used successfully in combination with one another in the neoadjuvant, concomitant, and adjuvant context for many years. However, despite their utility and curative potential, each modality has its limitations in terms of limited efficacy, significant toxicity, lack of durability of response, and in the case of chemotherapy the emergence of drug resistance. In addition to the release of neoantigens after tumor-cell destruction, exposure of cancer cells to cytotoxic agents may induce innate and adaptive immune responses against the cancer in other ways. Certain modes of cancer cell death are associated with immunogenicity through the induction of immunogenic cell-death (ICD) proteins, such as calreticulin, HSP70, ATP, and HMGB proteins. ${ }^{1}$ A number of cytotoxic agents have been shown to induce ICD, ${ }^{2}$ while others are capable of modulating the tumor microenvironment by reducing the function or number of suppressive immune cells (regulatory $\mathrm{T}$ cells $\left[\mathrm{T}_{\text {regs }}\right]$ and myeloid-derived suppressor cells [MDSCs]) or generating inflammatory cytokines (Table 1). ${ }^{3-137}$ Tumors treated with chemotherapy have also been shown to be more sensitive to cytotoxic T-lymphocyte (CTL) killing. ${ }^{51}$ Most of the evidence for ICD has been derived from murine models of human cancer. Relatively little is known about

submit your manuscript | www.dovepress.com 
Table I Mechanisms of immunomodulation caused by chemotherapy (chemo) alone, and synergy seen when combined with oncolytic virus

\begin{tabular}{|c|c|c|c|}
\hline $\begin{array}{l}\text { Chemotherapy } \\
\text { drug }\end{array}$ & Mechanism of immunomodulation caused by chemo alone & $\begin{array}{l}\text { Immunomodulation } \\
\text { reference }\end{array}$ & $\begin{array}{l}\text { Oncolytic virus- } \\
\text { chemo synergy }\end{array}$ \\
\hline \multirow[t]{11}{*}{ Cyclophosphamide } & Triggers TRAIL CD8 ${ }^{+} \mathrm{T}$ cell-mediated apoptosis & 3 & \\
\hline & $\begin{array}{l}\text { Induces proinflammatory production/induction of ICD marker } \\
\text { calreticulin/HMGBI }\end{array}$ & $4-6$ & \\
\hline & Decreased $T_{\text {reg }}$ function & 7-9 & 10,11 \\
\hline & CD8 ${ }^{+} \mathrm{T}$ cell-specific tumor activity & 7 & \\
\hline & Induces T-helper type I or 17 immunity & 12 & 11 \\
\hline & Decreases complement function & & 13 \\
\hline & Suppression of immune cell types & & 14,15 \\
\hline & Inhibits or delays viral neutralization response & & $14-23$ \\
\hline & Increases MDSCs & 24,25 & \\
\hline & Enhances DC function & 26 & \\
\hline & Synergy, but unknown immune function, if any & & 27,28 \\
\hline \multirow[t]{6}{*}{ Gemcitabine } & Decreases MDSCs & 29 & $29-31$ \\
\hline & Decreases neutralizing antibodies & 29 & 29 \\
\hline & Induces ICD marker calreticulin & 4 & \\
\hline & Induces ICD marker HMGBI & & 32,33 \\
\hline & Depletes B cells & 34 & 35 \\
\hline & Synergy, but unknown immune function, if any & & $32,36-45$ \\
\hline \multirow[t]{5}{*}{ Bortezomib } & Enhances DC function & 46 & \\
\hline & ICD and DAMP release & 14 & \\
\hline & Antitumoral immunity & & 47 \\
\hline & $\mathrm{CD}^{+} \mathrm{T}$ cell-mediated inhibition of tumor growth & 46 & \\
\hline & Synergy, but undefined immune function, if any & & 48,49 \\
\hline \multirow[t]{6}{*}{ Doxorubicin } & Induces ICD marker calreticulin & 4 & 50 \\
\hline & Granzyme B released by CTLs & 51 & \\
\hline & Induces type I IFN response & 52 & \\
\hline & Increases $\mathrm{T}_{\text {reg }}$ cells and significantly decreases NK cells & 53 & \\
\hline & Decreases B7-HI/PD-LI from cell surface & 54 & \\
\hline & Synergy, but undefined immune function, if any & & $55-59$ \\
\hline \multirow[t]{5}{*}{ Mitoxantrone } & Induces $\mathrm{DC} / \mathrm{T}$-cell tumor infiltrate & 60 & \\
\hline & Releases ATP & 60 & \\
\hline & Ecto-CRT, ecto-HSP70, and HMGBI & 61,62 & \\
\hline & Tumor antigen-specific $\mathrm{CD} 8^{+}$and $\mathrm{CD} 4^{+} \mathrm{T}$-cell activity & $60,63,64$ & 65 \\
\hline & Enhances DC function & 66 & \\
\hline \multirow[t]{3}{*}{ Temozolomide } & Decreases $T_{\text {reg }}$ function & 67 & \\
\hline & Tumor-specific T-cell responses & 68 & 68 \\
\hline & Synergy, but undefined immune function, if any & & $69-74$ \\
\hline \multirow[t]{3}{*}{ Docetaxel } & Decreases MDSCs, increases CD8 ${ }^{+} \mathrm{T}$ cells & 75 & \\
\hline & Enhances DC function & 75 & \\
\hline & Synergy, but unknown immune function, if any & & $76-82$ \\
\hline \multirow[t]{9}{*}{ Paclitaxel } & Granzyme B released by CTLs & 83 & \\
\hline & Induces ICD marker calreticulin & 4 & \\
\hline & Induces $\mathrm{MHC}$ & 84 & \\
\hline & Decreases $T_{\text {reg }}$ function & $85-87$ & \\
\hline & Induces T-helper type I immunity & 12 & \\
\hline & Type I IFN and HMGBI release in vitro & & 88 \\
\hline & NK cells essential for strong synergy & & 10 \\
\hline & Slows neutralizing antibodies (with carboplatin) & & 89 \\
\hline & Synergy, but unknown immune function, if any & & $90-99$ \\
\hline \multirow[t]{4}{*}{ 5-Fluorouracil } & CD8 ${ }^{+} \mathrm{T}$ cell-mediated apoptosis & 100 & \\
\hline & Induces carcinoembryonic antigen (CEA) & 101 & \\
\hline & Decreases MDSCs & 102 & \\
\hline & Synergy, but unknown immune function, if any & & $103-105$ \\
\hline \multirow[t]{3}{*}{ Cisplatin } & Decreases $T_{\text {reg }}$ function & 106 & \\
\hline & CD8 ${ }^{+} \mathrm{T}$ cell-specific tumor activity & 106 & \\
\hline & Granzyme B released by CTL & 50 & \\
\hline
\end{tabular}


Table I (Continued)

\begin{tabular}{|c|c|c|c|}
\hline $\begin{array}{l}\text { Chemotherapy } \\
\text { drug }\end{array}$ & Mechanism of immunomodulation caused by chemo alone & $\begin{array}{l}\text { Immunomodulation } \\
\text { reference }\end{array}$ & $\begin{array}{l}\text { Oncolytic virus- } \\
\text { chemo synergy }\end{array}$ \\
\hline & Enhances DC function, cytokine release, and cytotoxic $\mathrm{T}$-cell activation & & 107 \\
\hline & Synergy, but unknown immune function, if any & & $108-118$ \\
\hline \multirow[t]{2}{*}{ Mitomycin C } & Enhances DC function & 71,119 & \\
\hline & Synergy, but unknown immune function, if any & & $120-124$ \\
\hline Azadeoxycytidine & Enhances DC function & 71 & \\
\hline \multirow[t]{3}{*}{ Irinotecan } & Decreases $T_{\text {reg }}$ function & 125 & \\
\hline & NK cells essential & 126 & 126 \\
\hline & Synergy, but unknown immune function, if any & & $126-129$ \\
\hline \multirow[t]{7}{*}{ Rapamycin/everolimus } & Inhibition of T-cell proliferation & 130 & $|3|$ \\
\hline & Decreases DC maturation & 130 & \\
\hline & Increases $\mathrm{T}_{\text {reg }}$ cells & 130 & \\
\hline & Decreases cellular IFN & & 132 \\
\hline & Decreases cytokine release & & $|3|$ \\
\hline & Decreases antiviral antibody production & & 131,133 \\
\hline & Synergy, but unknown immune function, if any & & $132-136$ \\
\hline \multirow[t]{2}{*}{$5-A z a$} & Induces cancer testis antigen & 137 & \\
\hline & Induces MHC & 137 & \\
\hline
\end{tabular}

Abbreviations: ICD, immunogenic cell death; $T_{\text {reg }}$, regulatory T cell; MDSCs, myeloid-derived suppressor cells; DC, dendritic cell; DAMP, danger-associated molecular pattern; CTLs, cytotoxic T lymphocytes; NK, natural killer; MHC, major histocompatibility complex; TRAIL, TNF-related apoptosis inducing ligand; Ecto-CRT, ecto calreticulin.

the immunogenicity of chemotherapy in cancer patients. The combination of "immunogenic" or ICD-inducing chemotherapy with other anticancer treatment modalities capable of priming and/or propagating immune responses is now being evaluated. While the obvious candidates for combination are cancer vaccines, low doses of radiotherapy and immune-checkpoint inhibitors, there is an increasingly compelling case for combination of chemotherapy with oncolytic viruses (OVs). ${ }^{138}$

Despite being recognized as having the potential to treat cancer since the beginning of the 20th century, OVs are only now entering the clinical arena for certain cancers, following the successful evaluation of talimogene laherparepvec (T-vec) in malignant melanoma. ${ }^{139}$ OVs are live viruses that are selectively toxic to cancer cells. The basis of selectivity for cancer versus normal cells is based on cell entry (tumor cells expressing a receptor the virus uses to gain entry), impaired IFN response in cancer cells, or dysregulation in key signaling pathways, such as the RAS pathway, which would otherwise (eg, through the phosphorylation of PKR) allow the cell to negate the virus. Clinical trials involving OVs as single agents have largely been safe, demonstrated minimal toxicity, and in certain studies shown signs both of efficacy by radiological evaluation and the presence of live virus in tumor biopsies a week or more after treatment. ${ }^{140,141}$ However, the overall efficacy of single-agent OV therapy has at best been modest. The true potential of OVs may yet be realized through their combination with other treatment modalities, such as chemotherapy. As well as synergistic mechanisms of tumor-cell killing, combination with chemotherapeutics through careful sequencing may help to overcome some of the barriers in the tumor microenvironment thought to limit the efficacy of OVs. These include large tumor size, ${ }^{142}$ poor vasculature, ${ }^{143}$ elevated interstitial pressure, ${ }^{144}$ and physical barriers. ${ }^{145}$ One potential limitation of OVs that is regularly debated is the rapid generation of antiviral antibody responses a week or so following OV administration. There have been attempts to attenuate this response using such agents as cyclophosphamide (CPA; discussed later), but it is clear that despite high levels of neutralizing antibodies, further administrations of the same OV can traffic to the tumor environment and cause tumor kill. The OV is most likely protected from neutralizing antibodies by carriage (hitchhiking) on granulocytes, lymphocytes, and platelets to tumor cells in metastatic deposits. ${ }^{146}$ Recent preclinical and clinical studies have shown that combining chemotherapy with OVs may potentially be highly synergistic, improving on the efficacy of each modality alone (Table 1 ).

In this review, we explore the many ways in which chemotherapy and OVs have been considered in combination. The methods used by researchers have been based on cell lines using classical isobologram analysis, murine models, and in humans with a number of completed clinical trials. 
Cell-death mechanisms: immunogenic cell death is vital for cancer therapy

OV-mediated cell death does not fit exactly into one of the three classical categories of cell death (apoptosis, necrosis, and autophagy), and likewise cell-death pathways induced by chemotherapy can vary from agent to agent. Due to the physiological consequences associated with cell death, enormous effort has been invested into understanding the three main mechanisms. Apoptosis is vital for development and the maintenance of tissue homeostasis, and is generally considered to be a nonimmunogenic form of cell death, while necrosis, which is less coordinated and results in the release of proinflammatory cytokines, has been regarded as immunogenic. ${ }^{147}$ However, it is now clear that the boundaries between each classical celldeath pathway are not defined and there is often overlap. This has been demonstrated by the discovery of "immunogenic" apoptosis in tumor cells, which can be induced by specific chemotherapies, such as the anthracyclines and oxaliplatin (Figure 1). ${ }^{148,149}$ Similarly, OV-mediated cell death does not fit into either apoptosis or necrosis, but displays features of both, with variations between oncolytic viral types. In general, the immunogenic death (apoptosis, necrosis, autophagy, etc) of cancer cells involves a multistep process, beginning with the recognition of pathogen-associated molecular components, such as viral components, which cause such molecules as fractalkine, nucleotides, and ATP to be released, which in turn attract phagocytes or dendritic cells (DCs), and the expression of such signals as phosphatidylserine and calreticulin that aid recognition by phagocytes or DCs. Finally, danger-associated molecular patterns (DAMPs), such as HMGB1, are expressed. This enables dying tumor cells to lose the ability to induce tolerance and to stimulate powerful anticancer immune responses (Figure 1). Scientists have investigated many ways to increase the immunogenic effects seen with OVs, but it is becoming clearer that one way to complement the ICD mechanisms and the immunomodulatory effects (Table 1) seen with either therapy alone is to combine both OVs and chemotherapy to achieve either at least an additive or (even better) a synergistic result.

\section{Combining chemotherapeutic drugs with OV therapy Cyclophosphamide}

CPA is an alkylating agent that causes cross-linking of DNA, and is used in the management of countless tumor types.

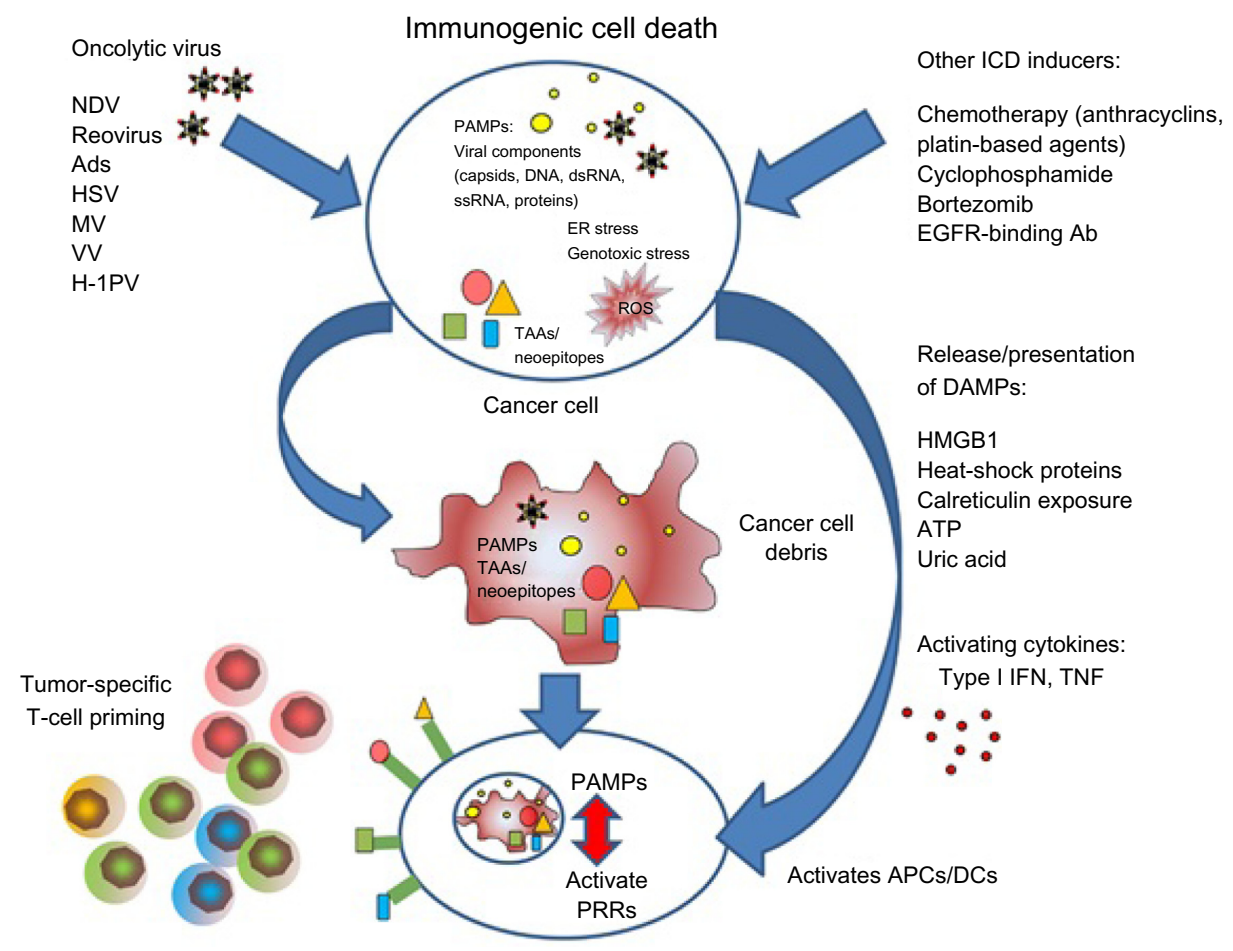

Figure I A summary of immunogenic cell death (ICD) caused by oncolytic virus and/or chemotherapy.

Note: Reproduced from Woller N, Gürlevik E, Ureche C-I, Schumacher A, Kühnel F. Oncolytic viruses as anticancer vaccines. Front Oncol. 20I4;4:I88. doi: 10.3389/fonc. 2014.00188 .148

Abbreviations: Ads, adenoviruses; APCs, antigen-presenting cells; DAMPs, danger-associated molecular patterns; DCs, dendritic cells; dsRNA, double-stranded RNA; EGFR, epidermal growth factor receptor; ER, endoplasmic reticulum; HSV, herpes simplex virus; IFN, interferon; MV, measles virus; NDV, Newcastle disease virus; PAMPs, pathogen-associated molecular patterns; PRRs, pattern recognition receptors; PV, parvovirus; ROS, reactive oxygen species; ssRNA, single-stranded RNA; TAAs, tumorassociated antigens; TNF, tumor necrosis factor; $\mathrm{V}$, vaccinia virus. 
In itself, CPA is not an active drug. It requires metabolic activation by aldehyde dehydrogenase, producing the active compound 4-hydroxycyclophosphamide. The release of HMGB1 and ecto-CRT is seen with CPA treatment, which results in DC activation, proinflammatory cytokine production, and T-cell proliferation. ${ }^{5,6}$ Synergy in vivo has been shown using a variety of OVs and CPA, including herpes simplex virus (HSV)-1, adenovirus, vaccinia, ${ }^{27,28}$ reovirus, measles, myxoma virus, ${ }^{15}$ and vesicular stomatitis virus (VSV). ${ }^{23}$ The combination of CPA with reovirus has been investigated in in vivo models, and these studies have demonstrated safety and efficacy using a carefully titrated CPA schedule, including administration 24 hours before reovirus. ${ }^{20}$ However, significant normal-tissue toxicity was seen at higher doses, similar to the administration of reovirus to B-cell knockout mice. ${ }^{20}$ Therefore, careful titration of any immunomodulatory effect is required to optimize efficacy without augmenting viral replication and toxicity in normal tissues. Studies with oncolytic HSV-1 and adenovirus in combination with CPA have shown a fall in the magnitudes of antiviral immune cells, which prevents, inhibits, or delays viral neutralization. ${ }^{14,17,19,21}$ CPA has been shown in vivo to deplete the complement response to HSV. ${ }^{13}$ With oncolytic measles virus and VSV, CPA has been shown to strongly damp down the antiviral host immune response, ${ }^{23,150}$ but in the case of a VSV combination resulted in reduced therapeutic efficacy compared to CPA alone. ${ }^{150}$ Zemp et al showed that the removal of the tumor-resident macrophage population in an orthotopic glioma model by CPA substantially increased the survival of mice with myxoma virus post-treatment. ${ }^{15}$

Additional studies imply that a CPA/viral combination can also boost antitumor immunity by inhibiting $\mathrm{T}_{\text {regs }}{ }^{10,11}$ These data were confirmed in a Phase I clinical trial that showed that metronomic dosing of CPA decreased $\mathrm{T}_{\text {regs }}$ in solid tumors treated with adenovirus granulocyte macrophage colony-stimulating factor, without compromising the stimulation of antitumor responses. ${ }^{11}$ In contrast, Phase I clinical trials showed that reovirus (where CPA dose was escalated from 25 to $1,000 \mathrm{mg} / \mathrm{m}^{2}$ ) or Seneca Valley virus coadministration with CPA were safe, but did not attenuate host antiviral responses. ${ }^{151,152}$

\section{Gemcitabine}

Gemcitabine is a fluorinated deoxycytidine analog that has two forms: the gemcitabine diphosphate form, which impedes the ribonucleotide reductase enzyme, resulting in a reduction in the pool of deoxynucleotide available for DNA synthesis; whereas the second form, gemcitabine triphosphate, is incorporated into
DNA, causing chain termination and resulting in apoptosis and cell death. Gemcitabine has also been shown to deplete MDSCs and promote antitumor immune responses. ${ }^{153}$ Both gemcitabine and CPA can decrease neutralizing antibodies in cancer patients. ${ }^{29}$ An increase in antitumor activity was seen with a wide array of OVs in combination with gemcitabine, including adenovirus, ${ }^{38-44}$ parvovirus, ${ }^{32,33}$ reovirus, ${ }^{30,37} \mathrm{VSV}^{35}$ $\mathrm{HSV}^{31}$ vaccinia, ${ }^{45}$ and myxoma virus. ${ }^{36}$ Gemcitabine alone fails to trigger HMGB1 release; in contrast, parvovirus does induce HMGB $1 .{ }^{32}$ Combination treatment of both parvovirus and gemcitabine results in a high level of tumor cytotoxicity without impeding ICD activities. ${ }^{32}$

In vivo studies with either HSV or reovirus in combination with gemcitabine improved the survival compared with either treatment alone. ${ }^{30,31}$ These therapeutic combinations also demonstrate that gemcitabine limits the reovirus/ HSV-1-induced accumulation of MDSCs in the tumor microenvironment. ${ }^{30,31}$ Gemcitabine treatment in a Phase I clinical trial showed greatly reduced levels of reovirus-neutralizing antibodies, and $80 \%$ of patients exhibited either a partial response or stable disease. ${ }^{29}$

\section{Bortezomib}

Bortezomib is a peptide-based, reversible proteasome inhibitor. Potent immunomediated antitumor effects were seen after treatment with bortezomib in the form of enhanced DC function and upregulation of the HSP60 and HSP90 proteins. ${ }^{46}$ Bortezomib has been shown to generate reactive oxygen species, which are believed to cause ICD and DAMP release, increasing cellular stress. ${ }^{154-157}$ A number of OVs have been studied in combination with bortezomib, including HSV- $1,{ }^{60}$ reovirus, ${ }^{49}$ adenovirus, ${ }^{47}$ and VSV. ${ }^{48}$ Both HSV-1 and reovirus have shown synergy, but the contribution of immunomodulatory effects of bortezomib and antitumor immune responses in vivo was not examined. ${ }^{49,156}$ Combining VSV and bortezomib resulted in antagonism in vitro, but in contrast synergy was seen in vivo. ${ }^{48}$ This may have been due to immune cells in vivo that were not present in the in vitro setting. The authors of this study cited an ovarian tumor mouse study that showed reduction in tumor growth facilitated by $\mathrm{CD}^{+}$T-cell function with bortezomib alone. ${ }^{46}$ In a hepatocellular carcinoma in vivo model, treatment with bortezomib and an adenovirus expressing human telomerase reverse-transcriptase resulted in caspase-dependent apoptosis and a reduction in the antiviral immune responses. ${ }^{47}$

\section{Doxorubicin}

Doxorubicin (Dox) is an anthracycline antibiotic that intercalates into the DNA double-helical structure. This 
intercalation process hinders unwinding and resealing of DNA for transcription, and thus inhibits cellular DNA replication. Dox also stimulates the rapid production of type I IFNs by tumor cells after activation of TLR3, resulting in the release of chemokine (CXCL10). ${ }^{52}$ A type I IFN gene signature-predicted response to Dox therapy has been seen in breast cancer patients..$^{52}$

These data suggest that Dox-mediated immune responses mimic those induced by viral pathogens. In addition to inducing ICD 4 and type I IFN secretion, Dox and other chemotherapeutics also increase the susceptibility of tumors to CTLs by increasing tumor-cell permeability to granzyme B released by the CTLs. ${ }^{51}$ The addition of Dox to adenovirus resulted in significantly increased expression of calreticulin in vitro. ${ }^{50}$ Synergy between Dox and other OVs, such as HSV$1,{ }^{55}$ measles, ${ }^{56}$ vaccinia, ${ }^{57}$ Coxsackie virus $21,{ }^{50}$ and VSV59 has been seen in vitro and in vivo, but no immunocomponent effects have yet been defined.

\section{Mitoxantrone}

Mitoxantrone (MTX) is a synthetic anthracenedione antineoplastic agent derived from the anthraquinone dye ametantrone, ${ }^{158}$ which is frequently used to manage prostate, leukemia, and breast cancer. ${ }^{159,160}$ It is structurally similar to Dox, with both drugs having a planar aromatic ring structure that enables them to interact with DNA by intercalation between base pairs. MTX can inhibit the activity of the nuclear enzyme DNA topoisomerase (II), interfere with RNA and cause the cross-linking of DNA and strand breaks, and produce reactive oxygen species. MTX is believed to lack cell-cycle phase specificity, because it has cytocidal effects on both proliferating and nonproliferating cells. ${ }^{161}$ MTX also has immunosuppressive properties, resulting in the inhibition of proinflammatory cytokines, such as TNF, IL-2, and IFN $\gamma$. It is therefore used in the management of multiple sclerosis. ${ }^{162}$ Cancer cells undergoing immunogenic apoptosis and autophagy after treatment with MTX express various DAMPs, such as ecto-HSP70, ATP, and HMGB-1, ${ }^{160,161}$ and stimulate the peripheral relocation of CRT. ${ }^{163}$ MTX treatment also increases uptake of tumor-associated antigens by antigen-presenting cells, resulting in establishment of antitumor activity by antigen-specific $\mathrm{CD} 8^{+}$and $\mathrm{CD} 4^{+} \mathrm{T}$ cells. ${ }^{59,63,64}$ Both in murine models ${ }^{76,77}$ and in human patients with cancer, ${ }^{146}$ antitumor immune responses induced by cancer cells undergoing ICD are associated with better clinical responses. A combination of HSV-1 with MTX failed to increase cytotoxicity or halt virus replication in vitro. ${ }^{65,164}$ In contrast, in vivo, the same combination provided significant survival benefit when administered locally to HER-2/neu subcutaneous tumors. ${ }^{65}$ This protective effect was facilitated by enhanced levels of tumor antigen-specific CTL cells and an increase in intratumoral infiltration of neutrophil cells. ${ }^{65}$ These results were confirmed by depleting CD4-, CD8-, and Ly6G-expressing cells from the model, showing that these cells are essential for enhanced efficacy. ${ }^{65}$

\section{Irinotecan}

Irinotecan is an antineoplastic enzyme inhibitor and shows activity against colorectal, lung, esophageal, and gastric cancers, leukemia, and lymphomas. Irinotecan inhibits the topoisomerase I-DNA complex and causes double-strand DNA breakage that results in cell death. In the clinic, irinotecan is used in combination with fluorouracil and leucovorin (FOLFIRI) in colon cancer patients. ${ }^{125}$ Treatment with the FOLFIRI combination significantly reduced the amount of $\mathrm{CD}^{+}{ }^{+} \mathrm{FoxP}^{+} \mathrm{T}_{\text {regs }}$ in patients, without altering the total number of lymphocytes or the population of $\mathrm{CD} 4^{+} \mathrm{T}$ lymphocytes. ${ }^{125}$ Irinotecan has been shown to inhibit HSV-1 viral replication and lytic oncolysis in colon cancer cell lines. ${ }^{164}$ In contrast, other groups show synergy with OVs/irinotecan, including HSV-1 encoding CYP2B1, ${ }^{127}$ reovirus, ${ }^{128}$ and Sindbis virus. ${ }^{126}$ However, only the study on Sindbis virus looked at immune components in irinotecan synergy, concluding that natural killer cells are essential for the process. ${ }^{126}$

\section{Temozolomide}

Temozolomide (TMZ) is an alkylating agent currently used as first-line therapy for glioma treatment, due to its DNAdamaging effect. ${ }^{165,166}$ Advanced melanoma patients treated with low-dose TMZ followed by DC (autologous tumor lysate) vaccination showed a reduction in circulating immunosuppressive FoxP3 ${ }^{+} \mathrm{T}_{\text {regs }}{ }^{67}$

Synergy has been recorded between TMZ and both HSV $^{69,71}$ and adenovirus. ${ }^{68,72-74}$ An unconventional patient study on various cancers treated with oncolytic adenovirus and a low dose of TMZ showed an upregulation of ICD signal HMGB1 and specific tumor T-cell responses, which resulted in disease control in $67 \%{ }^{68}$ of cases. These results are interesting, but are difficult to interpret, due to the large number of different types of adenoviruses used in this study and differences in doses of TMZ.

\section{PI3K-Akt-mTOR pathway inhibitors}

The PI3K-Akt-mTOR signaling cascade is well characterized and plays a crucial role in a variety of physiologic processes, including cell-cycle progression, differentiation, transcription, translation, apoptosis, motility, autophagy, anabolic processes (including protein and lipid synthesis), and metabolic 
processes (including normal glucose homeostasis). Activation of the PI3k-Akt-mTOR signaling pathway is implicated in tumorigenesis, and PI3K-Akt-mTOR is the most frequently mutated pathway in cancer. PI3K/Akt inhibitors show synergy with HSV-MG18L71 and adenovirus ZD55-TRAIL166, but immunocomponents were not studied. mTOR is a master regulator of cellular translation and also impacts translation of viral proteins. Rapamycin is able to inhibit mTOR $^{167,168}$ by forming a complex with FKBP12. ${ }^{141,169}$ This inhibits proliferation, which results in the induction of autophagy in cancer cells. ${ }^{130,170} \mathrm{~T}$ and $\mathrm{B}$ lymphocytes also show a decrease in cell function in the presence of rapamycin. ${ }^{171-175}$ Also, rapamycin exhibits significant antiangiogenesis and anticancer properties. ${ }^{133}$ Studies with an oncolytic HSV show that rapamycin enhances viral replication in vitro. ${ }^{134} \mathrm{~A}$ possible mechanism for this enhanced viral replication may be the reduction of cellular IFN, which has been seen with VSV/rapamycin in an in vivo glioma model. ${ }^{136}$ Studies with adenovirus have shown that rapamycin/everolimus can suppress the adenovirus innate response (TNF, IL-1 $\beta$, IL-6, IL-8, IL-10, IL-12, and IFNס) reduce T-cell infiltration and decrease anti-Ad antibody production and T-cell function. ${ }^{131,133}$ This suppression by rapamycin/everolimus of the host viral immune response may explain the improved efficacy of oncolytic HSV, ${ }^{134}$ VSV,${ }^{136}$ adenovirus, ${ }^{131,135}$ and myxoma virus ${ }^{15}$ in a number of in vivo models.

\section{Mitomycin C}

Mitomycins are a group of antineoplastic antibiotics, of which mitomycin C (MMC) is the most studied. MMC is an alkylating agent that cross-links DNA and is produced by Streptomyces caespitosus. Apoptosis can be induced by MMC, either by the caspase 3- and 8-dependent Fas-FasL pathway or via the activity of the NFKB pathway. ${ }^{176} \mathrm{MMC}$ has also been shown to maintain innate and adaptive immune responses in a major subpopulation of human blood DCs (slan DC). This has encouraged the design of clinical trials for tumor patients that are based on the simultaneous administration of tumor antigen-loaded DCs and MMC. ${ }^{119}$ Intracellular adhesion molecule-1 and decay accelerating factor, the viral entry receptors for Coxsackie virus A21, have been shown to be upregulated in the presence of MMC, leading to synergy between virus and drug. ${ }^{120} \mathrm{HSV}-1,{ }^{121-123}$ vaccinia,,${ }^{124}$ and adenovirus ${ }^{177}$ have all shown synergy with MMC, but these studies have not identified any immune-function mechanism.

\section{Docetaxel}

Docetaxel (Doc) has been shown to have a number of inhibitory functions on tumor cells, including inducing apoptosis, angiogenesis, and impeding gene-expression processes, ${ }^{178}$ but its primary anticancer function is via microtubule stabilization. Doc has been shown to decrease MDSCs and thus increase $\mathrm{CD} 8^{+} \mathrm{T}$-cell activity in a murine model of breast cancer. ${ }^{179}$ Oncolytic adenovirus, ${ }^{76-79}$ reovirus, ${ }^{80,81}$ and HSV- $1{ }^{82}$ have all shown synergy with Doc, but these studies have not identified any immune-function mechanism. Doc had no effect on the production of neutralizing antibodies to reovirus in a Phase I clinical trial. ${ }^{81}$

\section{5-Fluorouracil}

5-Fluorouracil (5-FU) is an antimetabolite drug that inhibits the enzyme thymidylate synthase and the incorporation of its metabolites into RNA and DNA. ${ }^{180} 5$-FU did not suppress the production of neutralizing antibodies against G207, but increased viral spread in subcutaneous hamster gallbladder tumors. ${ }^{105}$ Antitumor effects of 5-FU are mediated, at least in part, by its selective cytotoxic action on MDSCs. ${ }^{102}$ Exposure of colon and pancreatic cancer cells to 5-FU significantly antagonizes both wild-type HSV-1 replication and lytic oncolysis. ${ }^{164}$ In contrast, an HSV-1 mutant missing one copy of its ICP0, ICP4, and ICP34.5 gene (NV1066) resulted in enhanced viral replication.

\section{Cisplatin}

Cisplatin is a well-characterized alkylating agent used for the management of a wide range of cancers. As with other alkylating agents, its main mode of action is its ability to cross-link with the purine bases on the DNA. Cisplatin also interferes with DNA-repair mechanisms, which causes DNA damage, and subsequently induces apoptosis in tumor cells. ${ }^{181}$ Cisplatin can decrease $T_{\text {regs }}$ and enhance antigen-specific $\mathrm{CD} 8^{+}$T-cell activity in murine models, ${ }^{106}$ and almost completely abrogate the inflammatory cytokine gene upregulation induced by reovirus. ${ }^{115}$ In contrast, a parvovirus-cisplatin combination induced higher cytokine release than either agent alone, and also resulted in pronounced DC maturation and cytotoxic T-cell activation. ${ }^{107}$

\section{Discussion}

OVs have been shown to be safely combined with conventional cytotoxic agents and evaluation in clinical trials justified on the basis of potential synergy through direct cytotoxicity, indirect immunogenicity, and/or alteration of the tumor microenvironment. The number of agents in clinical trials reflects the potential for this approach, which has recently focused away from delivery of live viruses to tumor sites, tumor lysis, and debulking to the induction of antitumor immunity through local induction of ICD, which ultimately will result in abscopal 
effects on distant metastases. Although not yet formally addressed in studies, there would most likely be low likelihood of cross-resistance to either treatment modality.

A number of human studies have already exploited this potential, as exemplified by the US Food and Drug Administration approval of the agent T-Vec for the treatment of malignant melanoma. Ongoing human studies are evaluating both DNA and RNA viruses and wild-type agents, as well as modified agents expressing immunostimulatory gene products. Combination with immune-checkpoint inhibitors has swiftly followed, with signals already of increased response rates compared to virus or checkpoint inhibitor alone. ${ }^{182}$ This follows evidence in a preclinical in vivo melanoma model, the oncolytic Newcastle disease virus, in combination with an anti-CTLA-4 antibody (ipilimumab), that showed enhanced tumor infiltration by activated $\mathrm{CD} 8^{+}$ and $\mathrm{CD}^{+} \mathrm{T}$ cells and a reduction in $\mathrm{T}_{\text {regs }}{ }^{183}$ This model also showed a nearly $70 \%$ rate of cure with combination treatment compared to less than $25 \%$ for agents alone. Prolonged survival was also seen in the same in vivo melanoma model (B16.F10) when treated with a combination of anti PD-1 antibody and reovirus. ${ }^{184}$ It is most likely that in the near future, combination studies with OVs will focus largely on immune-checkpoint modulation, but this may be tempered in term of toxicities and high cost.

While the earliest combination studies of OVs with chemotherapeutic agents were focused on attenuation of the expected brisk neutralizing antiviral antibody response, there is huge potential for combinations based on the immunostimulatory effects of common cytotoxic agents. Recent studies have shown convincingly that many OVs can hitchhike on circulating blood cells, are protected from neutralizing antibodies, and reach tumor sites, so this end point of chemotherapyOV combination is now being considered less important. A key factor that may allow combination studies to evolve is that almost all human OV studies have been associated with minimal toxicity, and actual dose-limiting toxicities rarely achieved. Therefore, patients will not be expected to face new and additional side effects and lower quality of life beyond the known chemotherapeutic agent-toxicity profile.

Historically, chemotherapy has been thought to prompt cancer cell death in an immunogenically silent way, but extensive studies have shown that such treatment can induce humoral and cellular antitumor immunity and break immune tolerance to tumors. The more subtle detail of this potential centers around the dose and sequencing of agents: CPA is myelosuppressive at conventional doses, but immunomodulatory as a single dose in combination with immunotherapy, or may be used to delete $\mathrm{T}_{\text {regs }}$ by metronomic dosing. Furthermore, combination studies will logically exploit the natural tropism of certain OVs for tumor vasculature with chemotherapeutic agents with antiangiogenic potential or those that may cause vascular leakage to allow OV into that tumor microenvironment. ${ }^{185}$

There is huge potential for the combination of OVs with chemotherapeutics, but success will entail careful selection of the OV, the tumor model, the molecular dysregulation harbored by the malignancy, and the transgenes the OV carries, together with the best dose and sequencing with the most appropriate cytotoxic. The ideal disease setting and virus is not clear as yet, and further challenges will be evaluation of response to combination therapy and the contribution of an OV added to a classical three-drug regimen in a common setting, such as advanced breast or gastrointestinal cancers. Our wealth of experience with single- and multiagent chemotherapy regimens at least allows us a head start with clinical translation of combinations with OVs.

\section{Disclosure}

The authors report no conflicts of interest in this work.

\section{References}

1. Kroemer G, Galluzzi L, Kepp O, Zitvogel L. Immunogenic cell death in cancer therapy. Annu Rev Immunol. 2013;31:51-72.

2. Chen G, Emens LA. Chemoimmunotherapy: reengineering tumor immunity. Cancer Immunol Immunother. 2013;62:203-216.

3. van der Most RG, Currie AJ, Cleaver AL, et al. Cylophosphamide chemotherapy sensitizes tumor cells to TRAIL-dependent CD8+ T cellmediated immune attack resulting in suppression of tumor growth. PLoS One. 2009;4:e6982.

4. Zitvogel L, Kepp O, Senovilla L, Menger L, Chaput N, Kroemer G. Immunogenic tumor cell death for optimal anticancer therapy: the calreticulin exposure pathway. Clin Cancer Res. 2010;16:3100-3104.

5. Schiavoni A, Sistigu M, Valentini F, et al. Cyclophosphamide synergizes with type I interferons through systemic dendritic cell reactivation and induction of immunogenic tumor apoptosis. Cancer Res. 2011;77: 768-778.

6. Bracci L, Moschella F, Sestili P, et al. Cyclophosphamide enhances the antitumor efficacy of adoptively transferred immune cells through the induction of cytokine expression, B-cell and T-cell homeostatic proliferation, and specific tumor infiltration. Clin Cancer Res. 2007;13: 644-653.

7. Ghiringhelli F, Larmonier N, Schmitt E, et al. CD4+CD25+ regulatory T cells suppress tumor immunity but are sensitive to cyclophosphamide which allows immunotherapy of established tumors to be curative. Eur J Immunol. 2004;34:336-344.

8. Lutsiak ME, Semnani RT, De Pascalis R, Kashmiri SV, Schlom J, Sabzevari H. Inhibition of CD4+CD25+ T regulatory cell function implicated in enhanced immune response by low dose cyclophosphamide. Blood. 2005;105:2862-2868.

9. Taieb J, Chaput N, Schartz N, et al. Chemoimmunotherapy of tumors: cyclophosphamide synergizes with exosome based vaccines. J Immunol. 2006; 176:2722-2729.

10. Kottke T, Chester J, Ilett E, et al. Precise scheduling of chemotherapy primes VEGF-producing tumors for successful systemic oncolytic virotherapy. Mol Ther. 2011;19:1802-1812. 
11. Cerullo V, Diaconu I, Kangasniemi L, et al. Immunological effects of low-dose cyclophosphamide in cancer patients treated with oncolytic adenovirus. Mol Ther. 2011;19:1737-1746.

12. Machiels JP, Reilly RT, Emens LA, et al. Cyclophosphamide, doxorubicin, and paclitaxel enhance the antitumor immune response of granulocyte/macrophage colony stimulating factor-secreting whole-cell vaccines in HER-2/neu tolerized mice. Cancer Res. 2001;61: 3689-3697.

13. Ikeda K, Wakimoto H, Ichikawa $\mathrm{T}$, et al. Complement depletion facilitates the infection of multiple brain tumors by an intravascular replication-conditional herpes simplex virus mutant. J Virol. 2000;74 4765-7475.

14. Thomas MA, Spencer JF, Toth K, Sagartz JE, Phillips NJ, Wold WS. Immunosuppression enhances oncolytic adenovirus replication and antitumor efficacy in the Syrian hamster model. Mol Ther. 2008;16: $1665-1673$.

15. Zemp FJ, McKenzie BA, Lun X, et al. Cellular factors promoting resistance to effective treatment of glioma with oncolytic myxoma virus. Cancer Res. 2014;74:7260-7273.

16. Ikeda $\mathrm{K}$, Ichikawa $\mathrm{T}$, Wakimoto $\mathrm{H}$, et al. Oncolytic virus therapy of multiple tumors in the brain requires suppression of innate and elicited antiviral responses. Nat Med. 1999;5:881-887.

17. Wakimoto H, Fulci G, Tyminski E, Chiocca EA. Altered expression of antiviral cytokine mRNAs associated with cyclophosphamide's enhancement of viral oncolysis. Gene Ther. 2004;11:214-223.

18. Kambara H, Saeki Y, Chiocca EA. Cyclophosphamide allows for in vivo dose reduction of a potent oncolytic virus. Cancer Res. 2005;65: $11255-11258$.

19. Currier MA, Gillespie RA, Sawtell NM, et al. Efficacy and safety of the oncolytic herpes simplex virus rRp450 alone and combined with cyclophosphamide. Mol Ther. 2008;16:879-885.

20. Qiao J, Wang H, Kottke T, et al. Cyclophosphamide facilitates antitumor efficacy against subcutaneous tumors following intravenous delivery of reovirus. Clin Cancer Res. 2008;14:259-269.

21. Dhar D, Spencer JF, Toth K, Wold WS. Effect of preexisting immunity on oncolytic adenovirus vector INGN007 antitumor efficacy in immunocompetent and immunosuppressed Syrian hamsters. J Virol. 2009;83:2130-2139.

22. Moschella F, Valentini M, Aricò E, et al. Unraveling cancer chemoimmunotherapy mechanisms by gene and protein expression profiling of responses to cyclophosphamide. Cancer Res. 2011;71:3528-3539.

23. Peng KW, Myers R, Greenslade A, et al. Using clinically approved cyclophosphamide regimens to control the humoral immune response to oncolytic viruses. Gene Ther. 2013;20:255-261.

24. Salem ML, El-Naggar SA, Cole DJ. Cyclophosphamide induces bone marrow to yield higher numbers of precursor dendritic cells in vitro capable of functional antigen presentation to $\mathrm{T}$ cells in vivo. Cell Immunol. 2010;261:134-143.

25. Diaz-Montero CM, Salem ML, Nishimura MI, Garrett-Mayer E, Cole DJ, Montero AJ. Increased circulating myeloid-derived suppressor cells correlate with cancer stage, metastatic tumor burden, and doxorubicincyclophosphamide chemotherapy. Cancer Immunol Immunother. 2008;58:49-59.

26. Nakahara T, Uchi H, Lesokhin AM, et al. Cyclophosphamide enhances immunity by modulating the balance of dendritic cell subsets in lymphoid organs. Blood. 2010;115:4384-4392.

27. Hofmann E, Weibel S, Szalay AA. Combination treatment with oncolytic vaccinia virus and cyclophosphamide results in synergistic antitumor effects in human lung adenocarcinoma bearing mice. JTransl Med. 2014;12:197.

28. Lun XQ, Jang JH, Tang N, et al. Efficacy of systemically administered oncolytic vaccinia virotherapy for malignant gliomas is enhanced by combination therapy with rapamycin or cyclophosphamide. Clin Cancer Res. 2009;15:2777-2788.

29. Lolkema MP, Arkenau HT, Harrington K, et al. A phase I study of the combination of intravenous reovirus type 3 Dearing and gemcitabine in patients with advanced cancer. Clin Cancer Res. 2011;17: 581-588.
30. Gujar SA, Clements D, Dielschneider R, Helson E, Marcato P, Lee PW. Gemcitabine enhances the efficacy of reovirus-based oncotherapy through anti-tumour immunological mechanisms. $\mathrm{Br} J$ Cancer. 2014;110:83-93

31. Esaki S, Goshima F, Kimura H, Murakami S, Nishiyama Y. Enhanced antitumoral activity of oncolytic herpes simplex virus with gemcitabine using colorectal tumor models. Int J Cancer. 2013;132:1592-1601.

32. Angelova AL, Aprahamian M, Grekova SP, et al. Improvement of gemcitabine-based therapy of pancreatic carcinoma by means of oncolytic parvovirus H-1PV. Clin Cancer Res. 2009;15:511-519.

33. Angelova AL, Grekova SP, Heller A, et al. Complementary induction of immunogenic cell death by oncolytic parvovirus $\mathrm{H}-1 \mathrm{PV}$ and gemcitabine in pancreatic cancer. J Virol. 2014;88:5263-5276.

34. Nowak AK, Robinson BW, Lake RA. Gemcitabine exerts a selective effect on the humoral immune response: implications for combination chemo-immunotherapy. Cancer Res. 2002;62:2353-2358.

35. Hastie E, Besmer DM, Shah NR, et al. Oncolytic vesicular stomatitis virus in an immunocompetent model of MUC1-positive or MUC1-null pancreatic ductal adenocarcinoma. J Virol. 2013;87:10283-10294.

36. Wennier ST, Liu J, Li S, Rahman MM, Mona M, McFadden G. Myxoma virus sensitizes cancer cells to gemcitabine and is an effective oncolytic virotherapeutic in models of disseminated pancreatic cancer. Mol Ther. 2012;20:759-768.

37. Sei S, Mussio JK, Yang QE, et al. Synergistic antitumor activity of oncolytic reovirus and chemotherapeutic agents in non-small cell lung cancer cells. Mol Cancer. 2009;8:47.

38. Leitner S, Sweeney K, Oberg D, et al. Oncolytic adenoviral mutants with E1B19K gene deletions enhance gemcitabine-induced apoptosis in pancreatic carcinoma cells and anti-tumor efficacy in vivo. Clin Cancer Res. 2009;15:1730-1740.

39. Liu D, Kojima T, Ouchi M, et al. Preclinical evaluation of synergistic effect of telomerase-specific oncolytic virotherapy and gemcitabine for human lung cancer. Mol Cancer Ther. 2009;8:980-987.

40. Onimaru M, Ohuchida K, Nagai E, et al. Combination with low-dose gemcitabine and hTERT-promoter-dependent conditionally replicative adenovirus enhances cytotoxicity through their crosstalk mechanisms in pancreatic cancer. Cancer Lett. 2010;294:178-186.

41. Bhattacharyya M, Francis J, Eddouadi A, Lemoine NR, Halldén G. An oncolytic adenovirus defective in pRb-binding (d1922-947) can efficiently eliminate pancreatic cancer cells and tumors in vivo in combination with 5-FU or gemcitabine. Cancer Gene Ther. 2011;18: 734-743.

42. Cherubini G, Kallin C, Mozetic A, et al. The oncolytic adenovirus $\mathrm{Ad} \Delta \Delta$ enhances selective cancer cell killing in combination with DNAdamaging drugs in pancreatic cancer models. Gene Ther. 2011;18: 1157-1165.

43. Wang H, Satoh M, Chen GP, Li DC, Hamada H, Arai Y. E1A, E1B double-restricted adenovirus enhances the cytotoxicity and antitumor activity of gemcitabine to renal cell carcinoma. Chin Med J (Engl). 2011;124:1082-1087.

44. Kangasniemi L, Parviainen S, Pisto T, et al. Effects of capsid-modified oncolytic adenoviruses and their combinations with gemcitabine or silica gel on pancreatic cancer. Int J Cancer. 2012;131:253-263.

45. Yu YA, Galanis C, Woo Y, et al. Regression of human pancreatic tumor xenografts in mice after a single systemic injection of recombinant vaccinia virus GLV-1h68. Mol Cancer Ther. 2009;8:141-151.

46. Chang CL, Hsu YT, Wu CC, et al. Immune mechanism of the antitumor effects generated by bortezomib. J Immunol. 2012;189:3209-3220.

47. Boozari B, Mundt B, Woller N, et al. Antitumoural immunity by virus-mediated immunogenic apoptosis inhibits metastatic growth of hepatocellular carcinoma. Gut. 2010;59:1416-1426.

48. Yarde DN, Nace RA, Russell SJ. Oncolytic vesicular stomatitis virus and bortezomib are antagonistic against myeloma cells in vitro but have additive anti-myeloma activity in vivo. Exp Hematol. 2013;41: 1038-1049.

49. Carew JS, Espitia CM, Zhao W, et al. Reolysin is a novel reovirus-based agent that induces endoplasmic reticular stress-mediated apoptosis in pancreatic cancer. Cell Death Dis. 2013;4:e728. 
50. Siurala M, Bramante S, Vassilev L, et al. Oncolytic adenovirus and doxorubicin-based chemotherapy results in synergistic antitumor activity against soft-tissue sarcoma. Int J Cancer. 2015;136:945-954.

51. Ramakrishnan R, Assudani D, Nagaraj S, et al. Chemotherapy enhances tumor cell susceptibility to CTL-mediated killing during cancer chemotherapy in mice. J Clin Invest. 2010;120:1111-1114.

52. Sistgu A, Yamazaki T, Vacchelli E, et al. Cancer cell-autonomous contribution of type I interferon signaling to the efficacy of chemotherapy. Nat Med. 2014;20:1301-1309.

53. Zhao Q, Zhang W, Ning Z, et al. A novel oncolytic herpes simplex virus type 2 has potent anti-tumor activity. PLoS One. 2014;9:e93103.

54. Gebeh H, Lehe C, Barhoush E, et al. Doxorubicin down-regulates cell surface B7-H1 expression and up-regulates its nuclear expression in breast cancer cells: role of B7-H1 as an anti-apoptotic molecule. Breast Cancer Res. 2010;12:R48.

55. Bolyard C, Yoo JY, Wang PY, et al. Doxorubicin synergizes with 34.5ENVE to enhance antitumor efficacy against metastatic ovarian cancer. Clin Cancer Res. 2014;20:6479-6494.

56. Weiland T, Lampe J, Essmann F, et al. Enhanced killing of therapyinduced senescent tumor cells by oncolytic measles vaccine viruses. Int J Cancer. 2014;134:235-243.

57. Ruiz-Hernández E, Hess M, Melen GJ, et al. PEG-pHPMAm-based polymeric micelles loaded with doxorubicin prodrugs in combination antitumor therapy with oncolytic vaccinia viruses. Polym Chem. 2014: 1674-1681.

58. Skelding KA, Barry RD, Shafren DR. Enhanced oncolysis mediated by Coxsackievirus A21 in combination with doxorubicin hydrochloride. Invest New Drugs. 2012;30:568-581.

59. Schache P, Gürlevik E, Strüver N, et al. VSV virotherapy improves chemotherapy by triggering apoptosis due to proteasomal degradation of Mcl-1. Gene Ther. 2009;16:849-861.

60. Michaud M. Autophagy-dependent anticancer immune responses induced by chemotherapeutic agents in mice. Science. 2011;334: 1573-1577.

61. Apetoh L, Ghiringhelli F, Tesniere A, et al. The interaction between HMGB1 and TLR4 dictates the outcome of anticancer chemotherapy and radiotherapy. Immunol Rev. 2007;220:47-59.

62. Ghiringhelli F, Apetoh L, Tesniere A, et al. Activation of the NLRP3 inflammasome in dendritic cells induces IL-1 $\beta$-dependent adaptive immunity against tumors. Nat Med. 2009;15:1170-1178.

63. Obeid M, Tesniere A, Ghiringhelli F, et al. Calreticulin exposure dictates the immunogenicity of cancer cell death. Nat Med. 2007;13:54-61.

64. Obeid M. Ecto-calreticulin in immunogenic chemotherapy. Immunol Rev. 2007;220:22-34.

65. Workenhe S, Pol JG, Lichty BD, Cummings DT, Mossman KL. Combining oncolytic HSV-1 with immunogenic cell death-inducing drug mitoxantrone breaks cancer immune tolerance and improves therapeutic efficacy. Cancer Immunol Res. 2013;1:1-11.

66. Kaneno R, Shurin GV, Tourkova IL, Shurin MR. Chemomodulation of human dendritic cell function by antineoplastic agents in low noncytotoxic concentrations. J Transl Med. 2009;7:58.

67. Ridolfi L, Petrini M, Granato AM, et al. Low-dose temozolomide before dendritic-cell vaccination reduces (specifically) CD4+CD25++Foxp3+ regulatory T-cells in advanced melanoma patients. Transl Med. 2013;11:135.

68. Liikanen I, Ahtiainen L, Hirvinen ML, et al. Oncolytic adenovirus with temozolomide induces autophagy and antitumor immune responses in cancer patients. Mol Ther. 2013;21:1212-1223.

69. Aghi M, Rabkin S, Martuza RL. Effect of chemotherapy-induced DNA repair on oncolytic herpes simplex viral replication. J Natl Cancer Inst. 2006;98:38-50.

70. Yokoyama T, Iwado E, Kondo Y, et al. Autophagy-inducing agents augment the antitumor effect of telomerase-selve oncolytic adenovirus OBP-405 on glioblastoma cells. Gene Ther. 2008;15:1233-1239.

71. Kanai R, Rabkin SD, Yip S, et al. Oncolytic virus-mediated manipulation of DNA damage responses: synergy with chemotherapy in killing glioblastoma stem cells. J Natl Cancer Inst. 2012;104:42-55.
72. Alonso MM, Gomez-Manzano C, Jiang H, et al. Combination of the oncolytic adenovirus ICOVIR-5 with chemotherapy provides enhanced anti-glioma effect in vivo. Cancer Gene Ther. 2007;14:756-761.

73. Holzmüller R, Mantwill K, Haczek C, et al. YB-1 dependent virotherapy in combination with temozolomide as a multimodal therapy approach to eradicate malignant glioma. Int J Cancer. 2011;129:1265-1276.

74. Kostova Y, Mantwill K, Holm PS, Anton M. An armed, YB-1-dependent oncolytic adenovirus as a candidate for a combinatorial anti-glioma approach of virotherapy, suicide gene therapy and chemotherapeutic treatment. Cancer Gene Ther. 2015;22:30-43.

75. Kodumudi KN, Woan K, Gilvary DL, Sahakian E, Wei S, Djeu JY. A novel chemoimmunomodulating property of docetaxel: suppression of myeloid-derived suppressor cells in tumor bearers. Clin Cancer Res. 2010;16:4583-4594.

76. Miranda E, Pineda HM, Oberg D, et al. Adenovirus-mediated sensitization to the cytotoxic drugs docetaxel and mitoxantrone is dependent on regulatory domains in the E1ACR1 gene-region. PLoS One. 2012;7:e46617.

77. Radhakrishnan S, Miranda E, Ekblad M, et al. Efficacy of oncolytic mutants targeting $\mathrm{pRb}$ and $\mathrm{p} 53$ pathways is synergistically enhanced when combined with cytotoxic drugs in prostate cancer cells and tumor xenografts. Hum Gene Ther. 2010;21:1311-1325.

78. Mantwill K, Köhler-Vargas N, Bernshausen A, et al. Inhibition of the multidrug-resistant phenotype by targeting YB-1 with a conditionally oncolytic adenovirus: implications for combinatorial treatment regimen with chemotherapeutic agents. Cancer Res. 2006;66:7195-7202.

79. Zhang J, Ramesh N, Chen Y, et al. Identification of human uroplakin II promoter and its use in the construction of CG8840, a urotheliumspecific adenovirus variant that eliminates established bladder tumors in combination with docetaxel. Cancer Res. 2002;62:3743-3750.

80. Heinemann L, Simpson GR, Boxall A, et al. Synergistic effects of oncolytic reovirus and docetaxel chemotherapy in prostate cancer. BMC Cancer. 2011;11:221.

81. Comins C, Spicer J, Protheroe A, et al. REO-10: a phase I study of intravenous reovirus and docetaxel in patients with advanced cancer. Clin Cancer Res. 2010;16:5564-5572.

82. Passer BJ, Castelo-Branco P, Buhrman JS, Varghese S, Rabkin SD, Martuza RL. Oncolytic herpes simplex virus vectors and taxanes synergize to promote killing of prostate cancer cells. Cancer Gene Ther. 2009;16:551-560.

83. Ramakrishnan R, Assudani D, Nagaraj S, et al. Chemotherapy enhances tumor cell susceptibility to CTL-mediated killing during cancer chemotherapy in mice. $J$ Clin Invest. 2010;120:1111-1114.

84. Kaneno R, Shurin GV, Kaneno FM, Naiditch H, Luo J, Shurin MR. Chemotherapeutic agents in low noncytotoxic concentrations increase immunogenicity of human colon cancer cells. Cell Oncol (Dordr). 2011;116:222-233.

85. Zhang L, Dermawan K, Jin M, et al. Differential impairment of regulatory $\mathrm{T}$ cells rather than effector cells by paclitaxel-based chemotherapy. Clin Immunol. 2008;129:219-229.

86. Beyer M, Kochanek M, Darabi K, et al. Reduced frequencies and suppressive function of CD4+CD25hi regulatory $\mathrm{T}$ cells in patients with chronic lymphocytic leukemia after therapy with fludarabine. Blood. 2005;106:2018-2025.

87. Correale P, Cusi MG, Tsang KY, et al. Chemo-immunotherapy of metastatic colorectal carcinoma with gemcitabine plus FOLFOX 4 followed by subcutaneous granulocyte macrophage colony-stimulating factor and interleukin-2 induces strong immunologic and antitumor activity in metastatic colon cancer patients. J Clin Oncol. 2005;23:8950-8958.

88. Huang B, Sikorski R, Kirn DH, Thorne SH. Synergistic anti-tumor effects between oncolytic vaccinia virus and paclitaxel are mediated by the IFN response and HMGB1. Gene Ther. 2011;18:164-172.

89. Karapanagiotou EM, Roulstone V, Twigger K, et al. Phase I/II trial of carboplatin and paclitaxel chemotherapy in combination with intravenous oncolytic reovirus in patients with advanced malignancies. Clin Cancer Res. 2012;18:2080-2089. 
90. Shimoyama S, Goshima F, Teshigahara O, et al. Enhanced efficacy of herpes simplex virus mutant HF10 combined with paclitaxel in peritoneal cancer dissemination models. Hepatogastroenterology. 2007;54: 1038-1042

91. Lin SF, Gao SP, Price DL, et al. Synergy of a herpes oncolytic virus and paclitaxel for anaplastic thyroid cancer. Clin Cancer Res. 2008;14: $1519-1528$.

92. Zeng WG, Li JJ, Hu P, Lei L, Wang JN, Liu RB. An oncolytic herpes simplex virus vector, G47A, synergizes with paclitaxel in the treatment of breast cancer. Oncol Rep. 2013;29:2355-2361.

93. Zeng W, Hu P, Wu J, et al. The oncolytic herpes simplex virus vector G47D effectively targets breast cancer stem cells. Oncol Rep. 2013;29: 1108-1114.

94. Roulstone V, Twigger K, Zaidi S, et al. Synergistic cytotoxicity of oncolytic reovirus in combination with cisplatin-paclitaxel doublet chemotherapy. Gene Ther. 2013;20:521-528.

95. Cheong SC, Wang Y, Meng JH, et al. E1A-expressing adenoviral E3B mutants act synergistically with chemotherapeutics in immunocompetent tumor models. Cancer Gene Ther. 2008;15: 40-50.

96. Rognoni E, Widmaier M, Haczek C, et al. Adenovirus-based virotherapy enabled by cellular YB-1 expression in vitro and in vivo. Cancer Gene Ther. 2009;16:753-763.

97. Ingemarsdotter CK, Baird SK, Connell CM, Öberg D, Halldén G, McNeish IA. Low-dose paclitaxel synergizes with oncolytic adenoviruses via mitotic slippage and apoptosis in ovarian cancer. Oncogene. 2010;29:6051-6063.

98. Rein DT, Volkmer A, Bauerschmitz G, et al. Combination of a MDR1targeted replicative adenovirus and chemotherapy for the therapy of pretreated ovarian cancer. J Cancer Res Clin Oncol. 2012;138:603-610.

99. Tseng JC, Granot T, DiGiacomo V, Levin B, Meruelo D. Enhanced specific delivery and targeting of oncolytic Sindbis viral vectors by modulating vascular leakiness in tumor. Cancer Gene Ther. 2010;17: 244-255.

100. Yang S, Haluska FG. Treatment of melanoma with 5-fluorouracil or dacarbazine in vitro sensitizes cells to antigen-specific CTL lysis through perforin/granzyme- and Fas-mediated pathways. J Immunol. 2004; 172:4599-4608.

101. Correale P, Aquino A, Giuliani A, et al. Treatment of colon and breast carcinoma cells with 5-fluorouracil enhances expression of carcinoembryonic antigen and susceptibility to HLA-A*02/01-restricted, CEA-peptide specific cytotoxic T cells in vitro. Int J Cancer. 2003;104:437-445.

102. Vincent J, Mignot G, Chalmin F, et al. 5-Fluorouracil selectively kills tumor- associated myeloid-derived suppressor cells resulting in enhanced T cell-dependent antitumor immunity. Cancer Res. 2010;70: 3052-3061.

103. Sagawa T, Yamada Y, Takahashi M, et al. Treatment of hepatocellular carcinoma by AdAFPep/rep, AdAFPep/p53, and 5-fluorouracil in mice. Hepatology. 2008;48:828-840

104. Ma G, Kawamura K, Li Q, et al. Combinatory cytotoxic effects produced by E1B-55kDa-deleted adenoviruses and chemotherapeutic agents are dependent on the agents in esophageal carcinoma. Cancer Gene Ther. 2010;17:803-813.

105. Nakano K, Todo T, Zhao G, et al. Enhanced efficacy of conditionally replicating herpes simplex virus (G207) combined with 5-fluorouracil and surgical resection in peritoneal cancer dissemination models. J Gene Med. 2005;7:638-648.

106. Tseng CW, Hung CF, Alvarez RD, et al. Pretreatment with cisplatin enhances E7-specific CD8+ T cell-mediated antitumor immunity induced by DNA vaccination. Clin Cancer Res. 2008;14: 3185-3192.

107. Moehler M, Sieben M, Roth S, et al. Activation of the human immune system by chemotherapeutic or targeted agents combined with the oncolytic parvovirus H-1. BMC Cancer. 2011;11:464.

108. Yoon AR, Kim JH, Lee YS, et al. Markedly enhanced cytolysis by E1B-19kD-deleted oncolytic adenovirus in combination with cisplatin. Hum Gene Ther. 2006;17:379-390.
109. Takakura M, Nakamura M, Kyo S, et al. Intraperitoneal administration of telomerase-specific oncolytic adenovirus sensitizes ovarian cancer cells to cisplatin and affects survival in a xenograft model with peritoneal dissemination. Cancer Gene Ther. 2010;17:11-19.

110. Zhang S, Readinger JA, DuBois W, et al. Constitutive reductions in mTOR alter cell size, immune cell development, and antibody production. Blood. 2011;117:1228-1238.

111. You L, Wang Y, Jin Y, Qian W. Downregulation of Mcl-1 synergizes the apoptotic response to combined treatment with cisplatin and a novel fiber chimeric oncolytic adenovirus. Oncol Rep. 2012;27:971-978.

112. Ma B, Wang Y, Zhou X, et al. Synergistic suppression effect on tumor growth of hepatocellular carcinoma by combining oncolytic adenovirus carrying XAF1 with cisplatin. J Cancer Res Clin Oncol. 2015;141:419-429.

113. Ganesh S, Gonzalez-Edick M, Gibbons D, et al. Combination therapy with radiation or cisplatin enhances the potency of Ad5/35 chimeric oncolytic adenovirus in a preclinical model of head and neck cancer. Cancer Gene Ther. 2009;16:383-392.

114. Hingorani P, Zhang W, Lin J, Liu L, Guha C, Kolb EA. Systemic administration of reovirus (Reolysin) inhibits growth of human sarcoma xenografts. Cancer. 2011;117:1764-1774.

115. Pandha HS, Heinemann L, Simpson GR, et al. Synergistic effects of oncolytic reovirus and cisplatin chemotherapy in murine malignant melanoma. Clin Cancer Res. 2009;15:6158-6166.

116. Sung CK, Choi B, Wanna G, Genden EM, Woo SL, Shin EJ. Combined VSV oncolytic virus and chemotherapy for squamous cell carcinoma. Laryngoscope. 2008;118:237-242.

117. Mace AT, Harrow SJ, Ganly I, Brown SM. Cytotoxic effects of the oncolytic herpes simplex virus HSV1716 alone and in combination with cisplatin in head and neck squamous cell carcinoma. Acta Otolaryngol. 2007;127:880-887.

118. Adusumilli PS, Chan MK, Chun YS, et al. Cisplatin-induced GADD34 upregulation potentiates oncolytic viral therapy in the treatment of malignant pleural mesothelioma. Cancer Biol Ther. 2006;5:48-53.

119. Wehner R, Bitterlich A, Meyer N, et al. Impact of chemotherapeutic agents on the immunostimulatory properties of human 6-sulfo LacNAc+ (slan) dendritic cells. Int J Cancer. 2013;132:1351-1359.

120. Annels NE, Simpson G, Arif M et al. Oncolytic immunotherapy for the treatment of non-muscle invasive bladder cancer using intravesical coxsackievirus A2. Journal for ImmunoTherapy of Cancer. 2015; $3(2): 331$.

121. Bennett JJ, Adusumilli P, Petrowsky H, et al. Up-regulation of GADD34 mediates the synergistic anticancer activity of mitomycin C and $\gamma_{1} 34.5$ deleted oncolytic herpes virus (G207). FASEB J. 2004;18: 1001-1003.

122. Mullerad M, Bochner BH, Adusumilli PS, et al. Herpes simplex virus based gene therapy enhances the efficacy of mitomycin $\mathrm{C}$ for the treatment of human bladder transitional cell carcinoma. J Urol. 2005;174:741-746.

123. Simpson GR, Horvath A, Annels NE, et al. Combination of a fusogenic glycoprotein, pro-drug activation and oncolytic HSV as an intravesical therapy for superficial bladder cancer. Br J Cancer. 2012;106: 496-507.

124. Sturm JB, Hess M, Weibel S, et al. Functional hyper-IL-6 from vaccinia virus-colonized tumors triggers platelet formation and helps to alleviate toxicity of mitomycin $\mathrm{C}$ enhanced virus therapy. $J$ Transl Med. 2012;10:9.

125. Maeda K, Hazama S, Tokuno K, et al. Impact of chemotherapy for colorectal cancer on regulatory T-cells and tumor immunity. Anticancer Res. 2011;31:4569-4574.

126. Granot T, Meruelo D. The role of natural killer cells in combinatorial anti-cancer therapy using Sindbis viral vectors and irinotecan. Cancer Gene Ther. 2012;19:588-591.

127. Tyminski E, Lerpy S, Terada K, et al. Brain tumor oncolysis with replication conditional herpes simplex type 1 expressing the prodrug activating genes CYP2B1 and secreted human intestinal carboxylesterase, in combination with cyclophosphamide and irinotecan. Cancer Res. 2005;65:6850-6857. 
128. Maitra R, Seetharam R, Tesfa L, et al. Oncolytic reovirus preferentially induces apoptosis in KRAS mutant colorectal cancer cells, and synergizes with irinotecan. Oncotarget. 2014;5:2807-2819.

129. Ottolino-Perry K, Acuna SA, Angarita FA, et al. Oncolytic vaccinia virus synergizes with irinotecan in colorectal cancer. Mol Oncol. 2015;9:1539-1552.

130. Turnquist HR, Raimondi G. Immunoregulatory functions of mTOR inhibition. Nat Rev Immunol. 2009;9:324-337.

131. Jiang ZK, Johnson M, Moughon DL, Kuo J, Sato M, Wu L. Rapamycin enhances adenovirus-mediated cancer imaging and therapy in preimmunized murine hosts. PLoS One. 2013;8:e73650.

132. Lun X, Alain T, Zemp FJ, et al. Myxoma virus virotherapy for glioma in immunocompetent animal models: optimizing administration routes and synergy with rapamycin. Cancer Res. 2010;70(2):598-608.

133. Homicsko K, Lukashev A, Iggo RD. RAD001 (everolimus) improves the efficacy of replicating adenoviruses that target colon cancer. Cancer Res. 2005;65:6882-6890.

134. Fu X, Tao L, Rivera A, Zhang X. Rapamycin enhances the activity of oncolytic herpes simplex virus against tumor cells that are resistant to virus replication. Int J Cancer. 2011;129:1503-1510.

135. Lukashev AN, Fuerer C, Chen MJ, Searle P, Iggo R. Late expression of nitroreductase in an oncolytic adenovirus sensitizes colon cancer cells to the prodrug CB1954. Hum Gene Ther. 2005;16: 1473-1483.

136. Alain T, Lun X, Martineau Y, et al. Vesicular stomatitis virus oncolysis is potentiated by impairing mTORC1-dependent type I IFN production. Proc Natl Acad Sci U S A. 2010;107:1576-1581.

137. Adair SJ, Hogan KT. Treatment of ovarian cancer cell lines with 5-aza2 -deoxycytidine upregulates the expression of cancer-testis antigens and class I major histocompatibility complex-encoded molecules. Cancer Immunol Immunother. 2009;58:589-601.

138. Touchefeu Y, Franken P, Harrington KJ. Radiovirotherapy: principles and prospects in oncology. Curr Pharm Des. 2012;18:3313-3320.

139. Appleton ES, Turnbull S, Ralph C, et al. Talimogene laherparepvec in the treatment of melanoma. Expert Opin Biol Ther. 2015;15(10): 1517-1530.

140. Andtbacka RH, Kaufman HL, Collichio F, et al. Talimogene laherparepvec improves durable response rate in patients with advanced melanoma. J Clin Oncol. 2015;33:2780-2788.

141. Vidal L, Pandha HS, Yap TA, et al. A phase I study of intravenous oncolytic reovirus type 3 Dearing in patients with advanced cancer. Clin Cancer Res. 2008;14:7127-7137.

142. Cordaro TA, de Visser KE, Tirion FH, et al. Tumor size at the time of adoptive transfer determines whether tumor rejection occurs. Eur $J$ Immunol. 2000;30:1297-1307.

143. Bilbao R, Bustos M, Alzuguren P, et al. A blood-tumor barrier limits gene transfer to experimental liver cancer: the effect of vasoactive compounds. Gene Ther. 2000;7:1824-1832.

144. Stohrer M, Boucher Y, Stangassinger M, Jain RK. Oncotic pressure in solid tumors is elevated. Cancer Res. 2000;60:4251-4255.

145. Li ZY, Ni S, Yang X, Kiviat N, Lieber A. Xenograft models for liver metastasis: relationship between tumor morphology and adenovirus vector transduction. Mol Ther. 2004;9:650-657.

146. Adair RA, Roulstone V, Scott KJ, et al. Cell carriage, delivery, and selective replication of an oncolytic virus in tumor in patients. Sci Transl Med. 2012;4:138ra77.

147. Kroemer G, Galluzzi L, Vandenabeele P, et al. Classification of cell death: recommendations of the Nomenclature Committee on Cell Death 2009. Cell Death Differ. 2009;16:3-11.

148. Woller N, Gurlevik E, Ureche CI, Schumacher A, Kuhnel F. Oncolytic viruses as cancer vaccines. Front Oncol. 2014;4:188.

149. Tesniere A, Schlemmer F, Boige V, et al. Immunogenic death of colon cancer cells treated with oxaliplatin. Oncogene. 2010;29:482-491.

150. Willmon C, Diaz RM, Wongthida P, et al. Vesicular stomatitis virusinduced immune suppressor cells generate antagonism between intratumoral oncolytic virus and cyclophosphamide. Mol Ther. 2011;19: $140-149$
151. Roulstone V, Khan K, Pandha HS, et al. Phase I trial of cyclophosphamide as an immune modulator for optimizing oncolytic reovirus delivery to solid tumors. Clin Cancer Res. 2015;21:1305-1312.

152. Burke MJ, Ahern C, Weigel BJ, et al. Phase I trial of Seneca Valley Virus (NTX-010) in children with relapsed/refractory solid tumors: a report of the Children's Oncology Group. Pediatr Blood Cancer. 2015;62:743-750.

153. Le HK, Graham L, Cha E, Morales JK, Manjili MH, Bear HD. Gemcitabine directly inhibits myeloid derived suppressor cells in $\mathrm{BALB} / \mathrm{c}$ mice bearing 4T1 mammary carcinoma and augments expansion of T cells from tumor-bearing mice. Int Immunopharmacol. 2009;9:900-909.

154. Ling YH, Liebes L, Zou Y, Perez-Soler R. Reactive oxygen species generation and mitochondrial dysfunction in the apoptotic response to bortezomib, a novel proteasome inhibitor, in human H460 non-small cell lung cancer cells. J Biol Chem. 2003;278:33714-33723.

155. Verfaillie T, Garg AD, Agostinis P. Targeting ER stress induced apoptosis and inflammation in cancer. Cancer Lett. 2013;332:249-264.

156. Milani M, Rzymski T, Mellor HR, et al. The role of ATF4 stabilization and autophagy in resistance of breast cancer cells treated with bortezomib. Cancer Res. 2009;60:4415-4423.

157. Yoo JY, Hurwitz BS, Bolyard C, et al. Bortezomib-induced unfolded protein response increases oncolytic HSV-1 replication resulting in synergistic antitumor effects. Clin Cancer Res. 2014;20: 3787-3798.

158. Dunn CJ, Goa KL. Mitoxantrone: a review of its pharmacological properties and use in acute nonlymphoblastic leukaemia. Drugs Aging. 1996;9:122-147.

159. Petrylak DP, Tangen CM, Hussain MH, et al. Docetaxel and estramustine compared with mitoxantrone and prednisone for advanced refractory prostate cancer. $N$ Engl J Med. 2004;351:1513-1520.

160. Crespi MD, Ivanier SE, Genovese J, Baldi A. Mitoxantrone affects topoisomerase activities in human breast cancer cells. Biochem Biophys Res Commun. 1986;136:521-528.

161. Wiseman LR, Spencer CM. Mitoxantrone: a review of its pharmacology and clinical efficacy in the management of hormone-resistant advanced prostate cancer. Drugs Aging. 1997;10:473-485.

162. Cocco E, Marrosu MG.The current role of mitoxantrone in the treatment of multiple sclerosis. Expert Rev Neurother. 2014;14(6):607-616.

163. Pol J, Vacchelli E, Aranda F, et al. Trial watch: immunogenic cell death inducers for anticancer chemotherapy. Oncoimmunology. 2015;4:e1008866.

164. Kulu Y, Kawasaki H, Donahue JM, et al. Concurrent chemotherapy inhibits herpes simplex virus-1 replication and oncolysis. Cancer Gene Ther. 2013;20:133-140.

165. Wei W, Chen X, Ma X, Wang D, Guo Z.The efficacy and safety of various dose-dense regimens of temozolomide for recurrent highgrade glioma: a systematic review with meta-analysis. J Neurooncol. 2015125(2):339-349.

166. Fan CH, Liu WL, Cao H, Wen C, Chen L, Jiang G. $\mathrm{O}^{6}$-methylguanine DNA methyltransferase as a promising target for the treatment of temozolomide-resistant gliomas. Cell Death Dis. 2013;4:e876.

167. Tong Y, Zhu W, Huang X, et al. PI3K inhibitor LY294002 inhibits activation of the Akt/mTOR pathway induced by an oncolytic adenovirus expressing TRAIL and sensitizes multiple myeloma cells to the oncolytic virus. Oncol Rep. 2014;31:1581-1588.

168. Sarbassov DD, Ali SM, Sabatini DM. Growing roles for the mTOR pathway. Curr Opin Cell Biol. 2005;17:596-603.

169. Sarbassov DD, Ali SM, Sengupta S, et al. Prolonged rapamycin treatment inhibits mTORC2 assembly and Akt/PKB. Mol Cell. 2006;22: 159-168

170. Takeuchi H, Kondo Y, Fujiwara K, et al. Synergistic augmentation of rapamycin-induced autophagy in malignant glioma cells by phosphatidylinositol 3-kinase/protein kinase B inhibitors. Cancer Res. 2005;65: 3336-3346.

171. Sehgal SN. Sirolimus: its discovery, biological properties, and mechanism of action. Transplant Proc. 2003;35:7S-14S. 
172. Aagaard-Tillery KM, Jelinek DF. Inhibition of human B lymphocyte cell cycle progression and differentiation by rapamycin. Cell Immunol. 1994;156:493-507.

173. Hleb M, Murphy S, Wagner EF, et al. Evidence for cyclin D3 as a novel target of rapamycin in human T lymphocytes. J Biol Chem. 2004;279:31948-31955.

174. Nourse J, Firpo E, Flanagan WM, et al. Interleukin-2-mediated elimination of the p27Kip1 cyclin-dependent kinase inhibitor prevented by rapamycin. Nature. 2004;372:570-573.

175. Luan FL, Hojo M, Maluccio M, Yamaji K, Suthanthiran M. Rapamycin blocks tumor progression: unlinking immunosuppression from antitumor efficacy. Transplantation. 2002;73:1565-1572.

176. Kang YH, Lee KA, Ryu CJ, et al. Mitomycin C induces apoptosis via Fas/FasL dependent pathway and suppression of IL-18 in cervical carcinoma cells. Cancer. Lett. 2006;237:33-44.

177. Zhao GZ, Tan WL, Zheng SB, Wu YD, Xie Y, Zhu WH. [Cytotoxic effect of oncolytic virus combined with mitomycin against human bladder cancer cells in vitro and in vivo]. Nan Fang Yi Ke Da Xue Xue Bao. 2006;26:1623-1625, 1628. Chinese.

178. Herbst RS, Khuri FR. Mode of action of docetaxel - a basis for combination with novel anticancer agents. Cancer Treat Rev. 2003;29: $407-415$.
179. Kodumudi KN, Woan K, Gilvary DL, Sahakian E, Wei S, Djeu JY. A novel chemoimmunomodulating property of docetaxel: suppression of myeloid-derived suppressor cells in tumor bearers. Clin Cancer Res. 2010;16:4583-4594.

180. Longley DB, Harkin DP, Johnston PG. 5-Fluorouracil: mechanisms of action and clinical strategies. Nat Rev Cancer. 2003;3:330-338.

181. Dasari S, Tchounwou PB. Cisplatin in cancer therapy: molecular mechanisms of action. Eur J Pharmacol. 2014;740:364-378.

182. Johnson DB, Puzanov I, Kelley MC. Talimogene laherparepvec (T-VEC) for the treatment of advanced melanoma. Immunotherapy. 2015;7:611-619.

183. Zamarin D, Holmgaard RB, Subudhi SK, et al. Localized oncolytic virotherapy overcomes systemic tumor resistance to immune checkpoint blockade immunotherapy. Sci Transl Med. 2014;6:226ra32.

184. Rajani K, Parrish C, Kottke T, et al. Combination therapy with reovirus and anti-PD-1 blockade controls tumor growth through innate and adaptive immune responses. Mol Ther. Epub 2015 Aug 27.

185. Fang J, Nakamura H, Maeda $H$. The EPR effect: unique features of tumor blood vessels for drug delivery, factors involved, and limitations and augmentation of the effect. Adv Drug Deliv Rev. 2011;63: $136-151$.
Oncolytic Virotherapy

\section{Publish your work in this journal}

Oncolytic Virotherapy is an international, peer-reviewed, open access online journal publishing original research, study protocols, reviews, editorials and commentaries on all aspects of oncolytic virology, namely the application of oncolytic viruses for the treatment of cancer. Specific topics in the journal include: Rationale and theoretical aspects of oncolytic virotherapy including in vitro, in vivo and mathematical

Submit your manuscript here: http://www.dovepress.com/oncolytic-virotherapy-journal

\section{Dovepress}

modeling; and practical application and problem solving in the clinic including identification of potential responders through biomarkers and genetic profiling. The manuscript management system is completely online and includes a very quick and fair peer-review system, which is all easy to use. Visit http://www.dovepress.com/ testimonials.php to read real quotes from published authors. 